\title{
Soybean genotypes resistant to white mold in the field and in oxalic acid sensitivity tests
}

\section{Genótipos de soja resistentes ao mofo-branco em campo e em teste de sensibilidade ao ácido oxálico}

\author{
Gabriela Carolina Guimarães ANDRADE ${ }^{1}$; Renato CARRER FILHO²; Marcos Gomes da CUNHA ${ }^{3}$ \\ ${ }_{1}^{1}$ Doutora em Fitossanidade/Fitopatologia, Universidade Federal de Goiás, gabriela.andrade@bayer.com \\ ${ }^{2}$ Autor para correspondência, Doutor em Fitossanidade/Fitopatologia, Núcleo de Pesquisa em Fitopatologia, Setor \\ Fitossanitário, Universidade Federal de Goiás, Campus Samambaia, Rod. GO-462, 74.690-900, Goiânia, GO, Brasil. \\ E-mail: carrerfilho@hotmail.com \\ ${ }^{3}$ Ph.D. em Fitopatologia, Universidade Federal de Goiás, mgcunha1@gmail.com
}

Recebido em: 14-09-2017; Aceito em: 21-11-2017

\begin{abstract}
White mold, caused by the fungus Sclerotinia sclerotiorum, is considered the second most destructive disease affecting soybean crops. The pathogen is controlled by integrating different methods, including genetic resistance. However, genotype selection techniques often lack the desired efficiency. As such, the aim of this study was to use sensitivity to oxalic acid as a selection method for white mold-resistant soybean genotypes and compare the results against soybean S. sclerotiorum infection in two agroecosystems, namely Barreiras (Bahia state - BA) and Jataí (Goiás state - GO). Eleven genotypes were planted and evaluated in the Barreiras region and 10 in Jataí, three of which were common to both areas. Assessments in the field involved analyzing white mold incidence, growth cycle and yield. For the oxalic acid-based selection method, the soybean genotypes were exposed to a $20 \mathrm{mM}$ oxalic acid solution and wilting was assessed. In oxalic acid sensitivity testing, both the resistant and susceptible genotypes mirrored the resistance expressed under field conditions. Thus, oxalic acid sensitivity testing was considered suitable for use in breeding programs aimed at selecting white mold-resistant genotypes.
\end{abstract}

Additional keywords: Glycine max; plant breeding; Sclerotinia sclerotiorum.

\section{Resumo}

O mofo-branco-da-soja, causado por Sclerotinia sclerotiorum, é considerado a segunda doença mais destrutiva que acomete a cultura. O controle deste patógeno é realizado por meio de integração de métodos, dentre eles se destaca a resistência genética. Entretanto, métodos para seleção de genótipos resistentes, muitas vezes, não possuem eficiência desejada. Dessa maneira, o objetivo do trabalho foi utilizar o ácido oxálico como método de sensibilidade para avaliar e selecionar genótipos de soja resistentes ao mofo-branco e comparar com resultados de avaliação de soja a $S$. sclerotiorum, em dois agroecossistemas, Barreiras/BA e Jataí/GO. Na região de Barreiras, foram avaliados 11 genótipos, e na região de Jataí, 10 genótipos, sendo três genótipos plantados em ambas as regiões. As avaliações em campo constaram da análise de incidência de mofo-branco, ciclo e produtividade. Para o método do ácido oxálico, os genótipos de soja foram colocados em contato com solução de $20 \mathrm{mM}$ e avaliado o índice de murcha. No teste de sensibilidade ao ácido oxálico, tanto os genótipos mais resistentes como os mais suscetíveis corroboraram as expressões de resistência avaliadas em condições de campo. Dessa maneira, o teste de sensibilidade ao ácido oxálico foi considerado apto ao uso em programas de melhoramento que visam à seleção de genótipos resistentes ao mofo-branco.

Palavras-chave adicionais: Glycine max; melhoramento de plantas; Sclerotinia sclerotiorum.

\section{Introduction}

Soybean (Glycine $\max$ (L.) Merr.) is an economically important oilseed and one of the most widely grown crops in the world. Its yield is subject to a number of losses due to phytosanitary problems, such as weeds, pests and disease (Roy et al., 2000). Disease is one of the main causes of reduced yields, with damage affecting more than $60 \%$ of crops in some soybean producing regions (Cunha et al., 2010; Wrather et al., 2010). White mold, or Sclerotinia stem rot, is a major soybean disease caused by the necrotrophic fungus Sclerotinia sclerotiorum (Bolton et al., 2006).

Studies of these interactions show that $S$. sclerotiorum secret enzymes as endopolygalacturonase (endo-PG) that degrade the cell wall of the host, and oxalic acid as phytotoxins which are directly linked to pathogenicity/aggressiveness (Zhao et al., 2015). Oxalate has been reported as a major aggressive factor during $S$. sclerotiorum infection (Donaldson et al., 2001; Kim et al., 2008) since, in addition to degrading the cell wall via acidification and promoting rupture (Dutton \& Evans, 1996), it can sup- 
press plant resistance mechanisms (Huang et al., 2008).

The use of fungicides and resistant varieties has been the main control measures for this phytopathogen (Wrather et al., 2010) from both an economic and ecological perspective. Several studies have been conducted to determine resistance to white mold; however, inoculation techniques and selection methods under controlled conditions have proved inconsistent in predicting the reaction of cultivars in the field (Kim et al., 1999; Kim \& Diers, 2000; Hoffman et al., 2002; Juliatti et al., 2013). This is largely due to unstable expression resulting from different combinations of genotype, host and environmental variations, as well as cryptic pathogen variability within the $S$. sclerotiorum population (Kurle et al., 2001; Hoffman et al., 2002; Dunn et al., 2017).

Selection methods based on the physiological resistance of plants to white mold stand out for their importance and simplicity, such as the reaction of soybean genotypes to oxalic acid content (Zhao et al., 2015). Advantages of this technique include assessing a wide range of genotypes over a short time period, not needing to handle the pathogen and preventing errors resulting from the genetic variability of the fungus, as well as avoiding the effect of environmental variations when evaluating the genotypes under field conditions. The efficacy of this method was demonstrated by Kolkman and Kelly (2000), who found it was capable of selecting $S$. sclerotiorum-resistant genotypes in the common bean and, in sunflowers, Vasic et al. (2002) correlate tolerance to oxalic acid, in vitro, with resistance / susceptibility to Sclerotinia in field grown plants. For Sclerotium rolfsii var. delphinii and Hosta sp. plants, Xu et al. (2009) developed a rapid selection method to evaluate petiole rot-resistant host plants using oxalic acid as a screening technique under controlled conditions.

Given the global importance of soybean cultivation and concern about compromised production caused by increasing yield losses, the assessment of soybean resistance to white mold, with methods that produce consistent reactions and are correlated with field results, is a vital component of genotype selection. Thus, the aim of the present study was to evaluate soybean resistance to white mold using oxalic acid and compare the results with findings under field conditions in different agroecosystems.

\section{Material and methods}

Field experiments were carried out in the 2012/2013 growing season in areas naturally infected by Sclerotinia sclerotiorum in the municipalities of Barreiras (Bahia state - BA) and Jataí (Goiás state $\mathrm{GO}$ ), totaling two experiments. Planting in both regions used a conventional system, with four rows in each experimental plot and no chemical sprays to control white mold. Population density varied from 10 to 18 plants per linear meter, according to recommendations for the region provided by the plant breeding company.
In the municipality of Barreiras, 11 soybean genotypes were evaluated, 8 commercial cultivars and 3 breeding lines in the second year of value for cultivation and use (VCU) testing. In Jataí, 10 soybean genotypes were studied, 7 commercial cultivars and 3 breeding lines in the second year of value for cultivation and use (VCU) testing. Three of the commercial cultivars tested were common to both sites.

A randomized block design was used with three repetitions and 11 treatments for the Barreiras region, and 10 treatments for Jataí. The experimental plots consisted of four 6-meter long rows spaced $0.5 \mathrm{~m}$, with the study area of each plot consisting of the two central rows, disregarding $0.5 \mathrm{~m}$ at either end.

Disease incidence was evaluated 90 days after planting (DAP), when plants were in reproductive stages R4 to R6 (Fehr et al., 1971). The assessment was conducted in the two central rows of the plots using a 9-point grading system, where $1=0 \%$ of plants infected; $2=1$ to $10 \% ; 3=11$ to $20 \% ; 4=21$ to $35 \%$; $5=36$ to $50 \% ; 6=51$ to $65 \% ; 7=66$ to $75 \% ; 8=76$ to $85 \%$; and $9=>85 \%$ of plants infected. The yield was obtained by harvesting the two center rows of each plot. Yield was calculated in $\mathrm{kg} \mathrm{ha}^{-1}$ and bean moisture content determined using a Gehaka G600i portable moisture meter. The cycle of each genotype was quantified as the number of days between planting and physiological maturity, that is, phonological stage R7.

The data collected were submitted to analysis of variance and the means were compared by cluster analysis using the Scott-Knott test $(P<0.05)$ and Sisvar 5.3 software (Ferreira, 2010).

\section{Sensitivity of soybean genotypes to oxalic acid}

In order to determine the oxalic acid content used as quantification standard for sensitivity testing, seven soybean genotypes previously assessed in the field were used (Figure 1). Seeds from these genotypes were separated onto plastic trays containing sixty $5 \times 5 \mathrm{~cm}$ wells filled with Plantmax ${ }^{\circledR}$ substrate and kept in a greenhouse. Plants at phenological stage V2, corresponding to approximately $20 \mathrm{DAP}$, were cut at the base of the stem and used in the experiments (Kolkman \& Kelly, 2000). The stalks were introduced into a perforated Styrofoam sheet so that they were fully encased in the polystyrene foam, leaving only the lower section of each stalk protruding. The sheet was placed over a plastic tray $(44 \mathrm{~cm} \times 70 \mathrm{~cm} \times 15 \mathrm{~cm})$ containing 5 liters of oxalic acid at concentrations of $10 \mathrm{mM}, 20 \mathrm{mM}$ or $40 \mathrm{mM}$, with $\mathrm{pH}$ adjusted to 4.0 using $\mathrm{NaOH}$, immersing the exposed stalks.

The experiment used a completely randomized design with 10 repetitions and each plot was represented by one plant. The negative control was a beaker containing 1 liter of distilled water with $\mathrm{pH} 4.0$, adjusted using $\mathrm{HCl}$, and no oxalic acid. The experiment was performed in the late afternoon to minimize the effect of transpiration and prevent premature wilting. After 18 hours of immersion, the genotypes were assessed for their reaction to oxalic acid using the 
descriptive scale of disease incidence scores proposed by Kolkman and Kelly (2000), whereby $1=$ no visible symptoms; 2 = one leaf with wilting symptoms; 3 = two leaves with wilting symptoms; $4=$ three leaves with wilting symptoms; $5=$ collapse of petioles and $6=$ collapse of the main stem .

Next, all 18 genotypes, previously assessed in the field (Barreiras and Jataí), were analyzed using a $20 \mathrm{mM}$ oxalic acid solution with twenty repetitions and each plot represented by one plant in a completely randomized design.

The data were submitted to clustering analysis and resistance indices $(\mathrm{Rl})$ were grouped using the Scott-Knot test $(\mathrm{P}<0.05)$ and Sisvar 5.3 software (Ferreira, 2010).

\section{Results}

In the assessments of white mold incidence, genotypes in Barreiras were divided into four groups based on the level of disease resistance, according to the Scott-Knott test $(P<0.05)$. Accessions P98Y12, NA7337RR and P98Y30 made up group 1 and showed resistant $(R)$, with scores ranging from 1.30 to
1.90. This group consisted of 3 genotypes, all commercial cultivars. Group 2 contained the genotype P98Y51, exhibiting intermediate resistance (MR) and an incidence score of 3.6. Groups 3 and 4 showed moderately susceptible (MS) to susceptible (S) responses, with scores ranging between 5.0 and 8.0 and consisted of 7 genotypes, 4 commercial cultivars and 3 breeding lines (Table 1). Cultivars P98Y12, NA7337RR and P98Y30 exhibited the lowest disease incidence rates and their growth cycles were considered super early, medium and late for the region, respectively. Given its late cycle, which favors development of the disease, P98Y30 deserves special attention since it was found to be white mold resistant. These same varieties, which showed high resistance, achieved greater yields than the average for the region $\left(3,000 \mathrm{~kg} \mathrm{ha}^{-1}\right)$ (CONAB, 2015), but lower yields when compared to some genotypes that displayed moderate white mold incidence rates, such as P98Y51, P98Y70 and L2010017. For P98Y51, which displayed moderate resistance to white mold and was considered a late-cycling cultivar, yield differed from the remaining highly resistant genotypes (Table 1).

Table 1 - Sclerotinia sclerotiorum incidence rates, yield, growth cycle and oxalate sensitivity of different soybean genotypes evaluated in Barreiras-BA in the 2011/2012 growing season.

\begin{tabular}{|c|c|c|c|c|c|c|}
\hline \multirow{2}{*}{ Cultivars/ Lineage } & \multicolumn{2}{|c|}{ Disease Incidence } & \multicolumn{2}{|c|}{ Oxalate Sensitivity } & \multirow{2}{*}{$\begin{array}{c}\text { Yield }\left(\mathrm{kg} \mathrm{ha}^{-1}\right) \\
\text { Barreiras }\end{array}$} & \multirow{2}{*}{ Cycle (days) } \\
\hline & Barreiras & Field $R^{*}$ & Index & $\mathrm{R}^{*}$ & & \\
\hline P98Y12 & $1.3 \mathrm{a}$ & $\mathrm{R}$ & $2.35 \mathrm{a}$ & $\mathrm{R}$ & $3878.33 \mathrm{~b}$ & 113 \\
\hline NA7337RR & $1.6 \mathrm{a}$ & $\mathrm{R}$ & $2.71 \mathrm{~b}$ & MR & $4311.33 \mathrm{~b}$ & 108 \\
\hline P98Y30 & $1.9 \mathrm{a}$ & $\mathrm{R}$ & $2.16 \mathrm{a}$ & $\mathrm{R}$ & $4643.67 \mathrm{~b}$ & 122 \\
\hline P98Y51 & $3.6 \mathrm{~b}$ & MR & $3.90 \mathrm{~d}$ & $S$ & $5545.33 \mathrm{a}$ & 130 \\
\hline P98Y11 & $5.0 \mathrm{c}$ & MS & $2.65 \mathrm{~b}$ & MR & $4047.33 \mathrm{~b}$ & 110 \\
\hline P98Y70 & $5.3 \mathrm{c}$ & MS & $2.90 \mathrm{c}$ & MS & $5328.00 \mathrm{a}$ & 133 \\
\hline 2010L019 & $5.5 \mathrm{c}$ & MS & $3.25 \mathrm{c}$ & MS & $4701.33 \mathrm{~b}$ & 125 \\
\hline M7908RR & $5.6 \mathrm{c}$ & MS & $3.56 \mathrm{~d}$ & $S$ & $4267.33 \mathrm{~b}$ & 119 \\
\hline 2010L021 & $7.6 \mathrm{~d}$ & $S$ & $3.47 d$ & $S$ & $4836.33 \mathrm{a}$ & 124 \\
\hline M9144RR & $7.6 \mathrm{~d}$ & $S$ & $3.10 \mathrm{c}$ & MS & $4869.30 \mathrm{a}$ & 140 \\
\hline 2010L017 & $8.0 \mathrm{~d}$ & $S$ & $3.02 \mathrm{c}$ & MS & $4578.67 \mathrm{~b}$ & 115 \\
\hline CV (\%) & 18.54 & - & 28.48 & & 10.22 & - \\
\hline
\end{tabular}

Resistance reaction to white mold assessed in the field and to oxalic acid, where R=resistant; MR=moderately resistant; $\mathrm{MS}=$ moderately susceptible, $\mathrm{S}=$ susceptible and $\mathrm{nd}=$ not determined. Means followed by the same letter in the column do not differ according to the Scott-Knott test $(P<0.05)$.

In field testing in Jataí, two groups of cultivars were analyzed based on disease incidence rates, considering the 10 genotypes tested (Table 2). The first group was more resistant $(R)$, with incidence rates ranging from 1.3 to 3.3 , and consisted of 5 genotypes, namely 2 breeding lines and 3 commercial cultivars. Group 2 contained 5 genotypes (4 commercial cultivars and 1 breeding line) and was considered susceptible, with incidence varying between 5.6 and 7.3.
Genotypes 2010L011, NA7337RR, ANATA82, 2010L012 and POTENCIA showed lower disease incidence rates when compared to the remaining genotypes. In these varieties, considered $R$, yield was higher than the average for the region (around $3,120 \mathrm{~kg} \mathrm{ha}^{-1}$ ) (CONAB, 2015), but results differed when compared to genotypes susceptible to white mold (Table 2). 
Table 2 - Sclerotinia sclerotiorum incidence rates, yield, growth cycle and oxalate sensitivity of different soybean genotypes evaluated in Jataí-GO in the 2011/2012 growing season.

\begin{tabular}{|c|c|c|c|c|c|c|}
\hline \multirow{2}{*}{ Cultivars/ Lineage } & \multicolumn{2}{|c|}{ Disease Incidence } & \multicolumn{2}{|c|}{ Oxalate Sensitivity } & \multirow{2}{*}{$\frac{\text { Yield }\left(\mathrm{kg} \mathrm{ha}^{-1}\right)}{\text { Jataí }}$} & \multirow[t]{2}{*}{ Cycle (days } \\
\hline & Jataí & Field $\mathrm{R}^{\star}$ & Index & $\mathrm{R}^{\star}$ & & \\
\hline 2010L011 & $1.3 \mathrm{a}$ & $\mathrm{R}$ & $2.10 \mathrm{a}$ & $\mathrm{R}$ & $7484.00 \mathrm{a}$ & 108 \\
\hline NA7337RR & $1.6 \mathrm{a}$ & $\mathrm{R}$ & $2.71 \mathrm{~b}$ & MR & $4500.00 \mathrm{~b}$ & 123 \\
\hline ANTA82 & $1.6 \mathrm{a}$ & $\mathrm{R}$ & $3.25 c$ & MS & $5498.66 \mathrm{a}$ & 117 \\
\hline 2010L012 & $2.0 \mathrm{a}$ & $\mathrm{R}$ & $2.95 \mathrm{c}$ & MS & $5974.00 \mathrm{a}$ & 107 \\
\hline POTÊNCIA & $3.3 \mathrm{a}$ & $\mathrm{R}$ & $1.85 \mathrm{a}$ & $\mathrm{R}$ & $6402.00 \mathrm{a}$ & 115 \\
\hline M7211RR & $5.6 \mathrm{~b}$ & $S$ & $2.40 \mathrm{~b}$ & MR & $5132.00 \mathrm{~b}$ & 113 \\
\hline M7639RR & $5.7 \mathrm{~b}$ & $S$ & $3.90 \mathrm{~d}$ & $S$ & $4226.33 \mathrm{~b}$ & 118 \\
\hline P98Y11 & $6.3 \mathrm{~b}$ & $S$ & $2.65 \mathrm{~b}$ & MR & $4495.67 \mathrm{~b}$ & 119 \\
\hline 2010L005 & $6.7 \mathrm{~b}$ & $S$ & $2.70 \mathrm{~b}$ & MR & $5957.00 \mathrm{a}$ & 113 \\
\hline M7908RR & $7.3 \mathrm{~b}$ & $S$ & $3.56 \mathrm{~d}$ & $S$ & $3805.67 \mathrm{~b}$ & 125 \\
\hline CV (\%) & 22.0 & & 28.48 & & 15.41 & \\
\hline
\end{tabular}

Resistance reaction to white mold assessed in the field and to oxalic acid, where R=resistant; MR=moderately resistant; $\mathrm{MS}=$ moderately susceptible, $\mathrm{S}=$ susceptible and $\mathrm{nd}=$ not determined. Means followed by the same letter in the column do not differ according to the Scott-Knott test $(\mathrm{P}<0.05)$.

Among the genotypes assessed in the two regions, cultivar NA7337RR exhibited greater resistance and was classified as early cycling for Barreiras, which may have helped it escape infection; however, in Jataí, the same cultivar displayed a late growth cycle and resistant $(\mathrm{R})$ to $\mathrm{S}$. scletoriorum.
In relation to the sensitivity of soybean genotypes to oxalic acid, after 18 hours of exposure to different concentrations of oxalic acid, all the genotypes studied showed symptoms of wilting at all the concentrations tested, except M9144RR, which exhibited no symptoms at $10 \mathrm{mM}$. Wilting increased with a rise in oxalate concentration (Figure 1).

$\begin{array}{cccccc}\text { Sensitivity index to Oxalate } & \text { Genotypes } & \begin{array}{c}\text { Reaction } \\ \text { to Disease }{ }^{1}\end{array} & \text { Local } & \text { Denomination } \\ \text { Lineage }\end{array}$

Figure 1 - Sensitivity of soybean genotypes submitted to different concentrations of oxalic acid. ${ }^{1}$ Resistance reaction to white mold, previously assessed in the field, where R=resistant; MS=moderately susceptible and $\mathrm{S}=$ susceptible.

At $10 \mathrm{mM}$, mean wilting indices ranged from 1.00 to 1.82 , with cultivar M9144RR showing the lowest wilting index and breeding line L2010L019 the highest. At $20 \mathrm{mM}$, mean resistance indices varied from 1.75 to 3.32 , with cultivars P99R01 and L2010L019 displaying the lowest and highest index, respectively. At an oxalic acid concentration of $40 \mathrm{mM}$, the mean wilting indices of cultivars M9144RR and P98Y11 were between 3.38 and 4.45, respectively (Figure 1).

In sensitivity testing at different oxalate concentrations, the wilting indices assessed showed greater variation at $20 \mathrm{mM}$, with a difference of 1.57 between the highest and lowest index. At this concen- 
tration, the most and least susceptible genotypes displayed resistance and susceptibility reactions consistent with those observed in the field. Wilting index ranges were lower at $10 \mathrm{mM}$ and $40 \mathrm{mM}$, with a difference of 0.82 and 1.07 between the highest and lowest indices, respectively. As such, a concentration of $20 \mathrm{mM}$ was selected for the subsequent experiment with 18 genotypes.

Oxalic acid sensitivity testing $(20 \mathrm{mM})$, conducted for all the genotypes assessed in the field, revealed a significant difference between soybean accessions. The genotypes considered most resistant were cultivars POTÉNCIA, P98Y30 and P98Y12 and breeding line 2010L011, with average scores of 1.85 , $2.16,2.35$ and 2.10 , respectively (Table 1 ), while the most sensitive were cultivars P98Y51 and M7639RR, with a mean score of 3.9, and M7908RR and 2010L021, exhibiting means of 3.56 and 3.47, respectively.

\section{Discussion}

The results of disease assessments in the field indicate that, in addition to precocity (Yang et al., 1999), other traits that confer resistance to white mold interfere in low disease incidence rates, particularly in cultivars from different physiological maturity groups. Environmental conditions are known to affect host physiology. Genotypes from different maturity groups can express different degrees of susceptibility in distinct agroecosystems, especially when climactic conditions favor the development of white mold (Vidic et al., 2013).

In both this and other field studies (Yang et al., 1999; Hoffman et al., 2002), soybean genotypes exhibited moderate disease resistance combined with high yields. This may be due to the adaptability of the variety to the region and the effect of the expression of genes with quantitative traits on the host plant, which are responsible for modulating the complex resistance of soybean to white mold (Vuong, et al., 2008; Zhao et al., 2015). Genetic evidence of physiological white mold resistance and prevention mechanisms was found by Kim \& Diers (2000) when mapping three QTL genes. Two loci are related to prevention mechanisms and primarily associated with flowering time, plant height and/or lodging index. The third locus is likely responsible for the partial physiological resistance of the plant. Recent studies show that at least four different genomic regions are involved in the resistance response to white mold (Zhao et al., 2015).

Studies by Kim et al. (2008) show that oxalic acid is an important toxin in pathogenicity, used mainly by necrotrophic pathogens in interaction with their hosts. These same authors observed that fungal mutants of $S$. sclerotiorum with deficient oxalic acid production were not pathogenic.

However, genotypes that express moderately susceptible to susceptible responses to white mold and a degree of tolerance to Sclerotinia sclerotiorum in the field are undesirable because they do not prevent crop losses and may require more inoculum in the planting area, which prompts a rise in production costs and the application of chemical products.

In terms of resistance indices to oxalic acid, the oxalate concentration that best differentiated the genotypes was $20 \mathrm{mM}$, as observed in research conducted with the common bean (Gonçalves \& Santos, 2010). Both the genotypes most resistant to oxalic acid (POTÊNCIA, 2010L011, P98Y30 and P98Y12) and those with higher means, that is, most sensitive to oxalic acid (P98Y51, M7639RR, M7908RR and 2010L021), expressed reactions consistent with resistance evaluated in the field. As such, in addition to the advantage of not using the etiological agent and therefore eliminating pathogen aggressiveness variability (Kull et al., 2004), this method is also not associated with the climactic effects that interfere in disease incidence and progression (Souza et al., 2014). Thus, these results confirm the potential for oxalic acid use in plant breeding programs, initially as a mass selection method to identify white mold-resistance genotypes.

\section{Conclusions}

The oxalic acid method was promising in the selection of soybean genotypes resistant to white mold.

Field assessment in different agroecosystems stood out as an essential method to corroborate expressions of white mold resistance to oxalic acid.

\section{References}

Bolton MD, Thomma BPHJ, Nelson BD (2006) Sclerotinia sclerotiorum (Lib.) de Bary: biology and molecular traits of a cosmopolitan pathogen. Molecular Plant Pathology 7(1):1-16.

CONAB (2015) Companhia Nacional de Abastecimento. Acompanhamento da safra brasileira de grãos: safra 2014/15. Ministério do Planejamento, Orçamento e Gestão, Brasília. 119p.

Cunha WG, Tinoco MLP, Pancoti HL, Ribeiro RE, Aragão FJL (2010) High resistance to Sclerotinia sclerotiorum in transgenic soybean plants transformed to express an oxalate decarboxylase gene. Plant Pathology 59(4):654-660.

Donaldson PA, Anderson T, Lane BG, Davidson AL, Simmonds DH (2001) Soybean plants expressing an active oligomeric oxalate oxidase from the wheat gf-2.8 (germin) gene are resistant to the oxalate-secreting pathogen Sclerotina sclerotiorum. Physiological and Molecular Plant Pathology 59(1):297-307.

Dunn AR, Kikkert JR, Pethybridge SJ (2017) Genotypic characteristics in populations of Sclerotinia sclerotiorum from New York State, USA. Annals of Applied Biology 10(2):219-228. 
Dutton MV, Evans CS (1996) Oxalate production by fungi: Its role in pathogenicity and ecology in the soil environment. Canadian Journal of Microbiology 42:881-895.

Fehr WR, Caviness CE, Burmood DT, Pennington JS (1971) Stage of development descriptions for soybeans, Glycine $\max$ (L.) Merrill. Crop Science 11(6):929-931.

Ferreira DF (2010) Sisvar: a computer statistical analysis system. Ciência e Agrotecnologia 35(1):1039-1042.

Gonçalves PRC, Santos JB (2010) Physiological resistance of common bean cultivars and lines to white mold based on oxalic acid reaction. Annual Report of Bean Improvement Cooperative 53(1):236-237.

Hoffman DD, Diers BW, Hartman GL, Nickell CD, Nelson RL, Pedersen WL, Cober ER, Graef GL, Steadman JR, Grau CR, Nelson BD, Del Rio LE, Helms T, Anderson T, Poysa V, Rajcan I, Stienstra WC (2002) Selected soybean plant introductions with partial resistance to Sclerotinia sclerotiorum. Plant Disease 86(9):971-980.

Huang L, Buchenauer H, Han Q, Zhang X, Kang Z (2008) Ultrastructural and cytochemical studies on the infection process of Sclerotinia sclerotiorum in oilseed rape. Journal of Plant Diseases and Protection 115(1):9-16.

Juliatti FC, Sagata E, Juliatti BCM (2013) Ranqueamento de genótipos de soja com resistência parcial por diferentes métodos de inoculação de Sclerotinia sclerotiorum submetidos à análise de correlação. Bioscience Journal 29(3):681-689.

Kim HS, Diers BW (2000) Inheritance of partial resistance to sclerotinia stem rot in soybean. Crop Science 40(1):55-61.

Kim HS, Sneller CH, Diers BW (1999) Evaluation of soybean cultivars for resistance to sclerotinia stem rot in field environments. Crop Science 39(1):64-68.

Kim KS, Min JY, Dickman MB (2008) Oxalic acid is an elicitor of plant programmed cell death during Sclerotinia sclerotiorum disease development. Molecular Plant Microbe Interactions 21(2):605-612.

Kolkman JM, Kelly JD (2000) An indirect test using oxalate to determine physiological resistance to white mold in common bean. Crop Science 41(1):281-285.
Kull LS, Pedersen WL, Palmquist D, Hartman GL (2004) Mycelial compatibility grouping and aggressiveness of Sclerotinia sclerotiorum. Plant Disease 88(4):325-332.

Kurle JE, Grau CR, Oplinger ES, Mengistu A (2001) Tillage, crop sequence, and cultivar effect on sclerotinia stem rot incidence and yield in soybean. Agronomy Journal 93(5):973-982.

Roy KW, Baird RE, Abney TS (2000) A review of soybean (Glycine max) seed, pod, and flower mycofloras in North America, with methods and a key for identification of selected fungi. Mycopathologia 150(1):15-27.

Souza DA, Pereira FAC, Dias JA, Leite ME, Santos JB (2014) Reaction of common bean progenies to white mold derived from recurrent selection. Ciência Rural 44(4):583-587.

Vasic D, Skoric D, Taski K, Stosic L (2002) Use of oxalic acid for screening intact sunflower plants for resistance to Sclerotinia in vitro. Helia 25(36):145-152.

Vidic M, Dordevic V, Petrovic K, Miladinovic J (2013) Review of soybean resistance to pathogens. Field and Vegetable Crops Research 50(2):52-61.

Vuong TD, Diers BW, Hartman GL (2008) Identification of QTL for resistance to sclerotinia stem rot in soybean plant introduction 194639. Crop Science 48(6):22092214.

Wrather A, Shannon G, Balardin R, Carregal L, Escobar R, Gupta GK, Ma Z, Morel W, Ploper D, Tenuta A (2010) Effect of diseases on soybean yield in the top eight producing countries in 2006. Online Plant Health Progress doi: 10.1094/PHP-2010-0125-01-RS.

Xu Z, Gleason ML, Mueller DS (2009) Development of a Rapid Method Using Oxalic Acid to Assess Resistance Among Hosta Cultivars to Petiole Rot Caused by Sclerotium rolfsii var. delphinii. Online Plant Health Progress doi: 10.1094/PHP-2009-0128-01-RS

Yang XB, Lundeen P, Uphoff MD (1999) Soybean varietal response and yield loss caused by Sclerotinia sclerotiorum. Plant Disease 83(5):456-461.

Zhao X, Han Y, Li Y, Liu D, Sun M, Zhao Y, Li C, Li D, Yang Z, Huang L, Teng W, Qu L, Zheng H, Li W (2015) Loci and candidate gene identification for resistance to Sclerotinia sclerotiorum in soybean (Glycine max L. Merr.) via association and linkage maps. The Plant Journal 82(3):245-255. 